\title{
Identitas Etnik dan Asertivitas Mahasiswa Suku Sunda
}

\author{
Muhammad Zaki Perceka ${ }^{1}$, Irfan Fahmi ${ }^{2}$, Elisa Kurniadewi ${ }^{3}$ \\ ${ }^{1,2,3}$ Fakultas Psikologi, Universitas Islam Negeri Sunan Gunung Djati, Bandung \\ e-mail:irfan.fahmi@uinsgd.ac.id
}

\begin{tabular}{|c|c|}
\hline Abstract/ Abstrak & Keywords/ Kata kunci \\
\hline $\begin{array}{l}\text { The study was conducted to determine effect of ethnic identity on assertiveness of } \\
\text { Sundanese students. The role of students who should be critical and responsive to } \\
\text { various things, but less prominent in Sundanese students in consequence of } \\
\text { existence of cultural rules require maintaining communication prefer to harbor } \\
\text { personal opinions and feelings. The demands of role and acculturation occur on } \\
\text { campus lead to high quality of ethnic identity negatively affecting assertive } \\
\text { communication skills. The research uses correlational quantitative methods. The } \\
\text { results showed the number of Sundanese students with a high level of ethnic } \\
\text { identity tended to be more than the low level of ethnic identity. While the quality } \\
\text { of assertive communication is high or low is not much different. Using the simple } \\
\text { regression calculation method shows that ethnic identity has a positive effect on } \\
\text { the assertiveness of Sundanese students. }\end{array}$ & $\begin{array}{l}\text { ethnic identity; } \\
\text { assertiveness; } \\
\text { sundanese }\end{array}$ \\
\hline $\begin{array}{l}\text { Penelitian dilakukan untuk mengetahui pengaruh identitas etnik terhadap } \\
\text { asertivitas mahasiswa suku Sunda. Peranan mahasiswa yang seharusnya kritis dan } \\
\text { tanggap terhadap berbagai hal tidak begitu menonjol pada mahasiswa Sunda } \\
\text { disebabkan adanya aturan budaya yang mengharuskan menjaga komunikasi agar } \\
\text { tidak menyakiti lawan bicara dan lebih memilih untuk memendam pendapat dan } \\
\text { perasaan pribadi. Tuntutan peran dan proses akulturasi yang terjadi di kampus } \\
\text { menimbulkan kualitas identitas etnik yang tinggi dapat berdampak pada } \\
\text { kemampuan komunikasi secara asertif. Penelitian menggunakan metode } \\
\text { kuantitatif korelasional. Hasil penelitian menunjukkan jumlah mahasiswa suku } \\
\text { Sunda dengan tingkat identitas etnik tinggi cenderung lebih banyak dibandingkan } \\
\text { dengan tingkat identitas etnik yang rendah. Sedangkan kualitas komunikasi asertif } \\
\text { yang tinggi maupun rendah tidak jauh berbeda. Hasil uji regresi sederhana } \\
\text { menunjukkan bahwa identitas etnik berpengaruh positif terhadap asertivitas } \\
\text { mahasiswa suku Sunda. }\end{array}$ & $\begin{array}{l}\text { identitas etnik; } \\
\text { asertivitas; } \\
\text { sunda }\end{array}$ \\
\hline
\end{tabular}

\section{Pendahuluan}

Indonesia merupakan negara yang masyarakatnya berasal dari latar belakang yang beragam. Keberagaman ini memerlukan adanya pemaknaan diri individu terhadap kelompok etniknya agar bisa membedakan antara satu etnik dengan etnik lainnya atau yang dinamakan dengan identitas etnik (Arandia, Sotres-Alvarez, Siega-Riz, Arredondo, Carnethon, Delamater, \& Perreira, 2018). Sunda merupakan salah satu etnik besar dari sekian banyak etnik di Indonesia. Menurut Badan Pusat Statistik (2011) setidaknya ada 36 juta jiwa yang beretnik Sunda. Jumlah tersebut menjadikan etnik Sunda menjadi salah satu yang terbesar di Indonesia.
Kriteria seseorang dapat dikategorikan orang Sunda apabila dirinya mengaku orang Sunda serta orang lain mengakuinya juga. Orang lain yang mengakuinya itu bisa dari kalangan orang Sunda sendiri atau selain orang Sunda. Karakteristik tersebut kemudian termanifestasikan ke dalam aspek kehidupan orang Sunda sehari-hari (Bennett, 2015). Masyarakat Sunda dikenal sebagai masyarakat yang ingin dipandang baik oleh orang lain, sesuai dengan pernyataan Rosidi (2010) bahwa masyarakat Sunda sudah dijajah sangat lama dan memiliki mental untuk terpakai oleh majikan atau atasan. Keinginan untuk selalu dipandang baik dan terpakai oleh orang lain ini terus melekat pada jati diri masyarakat Sunda dan sudah menjadi identitas etnik. Selain itu, 
penelitian yang dilakukan oleh Rahman, Sarbini, Tarsono, Fitriah, dan Mulyana (2018) menunjukkan karakteristik orang Sunda sebagai seseorang yang mudah bergaul, suka bergotong-royong, dan ramah.

Dalam konsep Psikologi, karakteristik, kepercayaan dan kebiasaan khas yang ditunjukkan dari suatu suku atau etnik disebut identitas etnik (Fisher, Zapolski, Sheehan, \& BarnesNajor, 2017). Iwamoto dan Liu (2010) mengungkapkan bahwa identitas etnik merupakan sebuah konstruksi yang multidimensi yang mencakup perilaku, pengetahuan dan keyakinan terhadap etnik serta tradisi dari etnik itu. Sedangkan Phinney (1992) mendefinisikan identitas etnik sebagai suatu konstruk yang rumit dengan mencakup komitmen dan perasaan kebersamaan pada suatu kelompok, evaluasi positif tentang kelompoknya, adanya minat dan pengetahuan tentang kelompok, serta keikutsertaan dalam aktivitas sosial dari kelompok. Phinney dan Ong (2007) menjelaskan terdapat dua aspek untuk mengetahui identitas etnik seseorang yaitu commitment dan exploration.

Commitment atau rasa memiliki merupakan komponen paling penting dari identitas etnik. Aspek ini mencakup tentang bagaimana cara bersikap dan sudut pandang yang dimiliki individu (Stets \& Fares, 2019). Selain itu, commitment juga dapat mendefinisikan sejauhmana identitas etnik yang dimiliki individu, apakah berdasarkan hasil didikan orang tuanya atau individu itu mampu memaknai dan mengaplikasikan nilai dari identitas etniknya. Sedangkan exploration didefinisikan sebagai sejauhmana individu menggali informasi dan pengalaman yang relevan dengan etnik individu tersebut. Proses yang biasanya dilakukan dalam exploration ini bisa dengan cara membaca literatur, bertanya kepada orang yang paham dengan etnik yang dimilikinya, mempelajari praktik budaya yang dimiliki serta menghadiri kegiatan budaya yang dilaksanakan (Dimitrova, Ferrer-Wreder, \& Trost, 2015; Stets \& Fares, 2019). Proses exploration biasanya terjadi pada usia remaja, namun ini merupakan proses yang terus berlanjut bahkan seumur hidup.

Selain ada keinginan untuk selalu terpakai, peneliti menemukan fenomena bahwa masyarakat Sunda memiliki nilai yang mengharuskan membuat orang lain merasa nyaman dan tidak terganggu, hal ini membuat masyarakat Sunda lebih memilih untuk menyembunyikan perasaan yang dialami dari pada harus berterus terang tentang perasaannya (Fathurroja, Mumtazah, Rosiana, Pudoli, \& Fridayanti, 2018). Dalam konsep Psikologi, ketidakmampuan berterus terang dengan keadaan yang sebenarnya kepada orang lain disebut tidak asertif.

Peneliti beranggapan banyak faktor yang menyebabkan seseorang tidak mampu berkomunikasi secara asertif, bisa diakibatkan karena terlalu mudah mengalah, mudah tersindir dan was-was, ragu-ragu pada diri sendiri, dan sulit untuk menjalin komunikasi dengan orang lain (Bigman, Mello, Sanders-Jackson, \& Tan, 2018; Fuspita, Susanti, \& Dewi, 2018). Ketidakmampuan untuk berkomunikasi secara terbuka ini dalam konsep Psikologi disebut tidak asertif. Menurut Townen (dalam Uyun \& Hadi, 2005) bahwa pribadi yang asertif biasanya terbuka kepada orang lain meskipun berbeda sudut pandang, mampu mengekspresikan diri dengan jelas, serta mampu menjalin komunikasi secara efektif.

Menurut Llyod (dalam Andayani dan Mardianto, 2015) komunikasi asertif merupakan suatu kompetensi sosial yang dapat menghilangkan kendala dalam berkomunikasi dan berinteraksi dengan orang lain. Orang yang sudah mampu berkomunikasi secara asertif akan mampu mengurangi tingkat konflik yang dirasakan sehingga dapat menghindari stres (Friedberg, 2014). Ketika seseorang telah mampu berkomunikasi secara asertif maka dia bisa menyampaikan argumen, sanggahan atau masukan apabila tidak setuju terhadap pandangan orang lain (Friedberg, 2014).

Dimensi asertivitas menurut Alberti dan Emmons (2017) setidaknya terdiri dari lima dimensi, yaitu: 1) berperilaku sejalan dengan kehendak pribadinya; 2) dapat mengungkapkan perasaan yang sebenarnya serta aman; 3) dapat 
membela diri sendiri; 4) mengungkapkan hakhak pribadi; serta 5) mempromosikan kesetaraan dan tidak menampik hak orang lain. Dimensi pertama mencakup kompetensi dalam mengambil keputusan, kemampuan berinisiatif, yakin terhadap hal yang dikemukakan, dapat memutuskan arah tujuan dan berusaha meraihnya serta mampu bergaul dalam lingkungan sosial. Dimensi kedua mencakup kemampuan untuk mengungkapkan perasaan tidak setuju, rasa marah, mengungkapkan dukungan serta bersikap spontan, memperlihatkan keramahan dan silaturahmi terhadap orang lain serta mengakui perasaan gamang atau resah, mengungkapkan persetujuan. Dimensi ketiga meliputi kompetensi untuk mengatakan "tidak" jika diperlukan, mampu menjawab kritik, kecaman atau amarah dari orang lain secara lugas serta bersedia mengutarakan dan teguh dengan pendapat sendiri. Dimensi keempat meliputi kompetensi dalam mengungkapkan ide dan pendapat, melakukan inovasi serta mampu merespon kejanggalan yang berhubungan dengan individu tersebut dan orang di luar dirinya. Dimensi kelima mencakup kompetensi dalam menyampaikan masukan dengan tepat serta tidak menekan, memutarbalikkan fakta, menekan, mengatur, serta mencederai orang lain.

Eisler, Miller dan Hersen, (dalam Parham, Lewis, Fretwell, Irwin, \& Schrimsher, 2015) menjelaskan aspek dari asertivitas adalah complience, duration of reply, loudness, request for new behavior, affect, latency of response, dan nonverbal behavior. Complience berhubungan dengan upaya individu dalam rangka menyangkal atau berlainan pendapat dengan orang lain. Duration of reply yaitu durasi yang dibutuhkan seseorang untuk mengutarakan apa yang hendak disampaikan kepada orang lain.

Loudness yaitu volume suara dalam komunikasi. Volume yang lebih lantang dianggap lebih asertif, selama tidak berteriak. Selain berbicara dengan volume suara yang keras, berbicara dengan artikulasi yang jelas juga merupakan metode komunikasi yang efektif dengan orang lain. Request for new behavior meliputi kemampuan untuk menyuruh orang lain berperilaku sesuai dengan keinginannya, mengungkapkan kenyataan atau emosi ketika memberi saran pada orang lain, tujuannya agar situasinya bisa sesuai dengan ekspektasi. Affect maksudnya adalah kemampuan individu untuk berucap sesuai dengan kondisi emosi yang dirasakannya. Pesan yang diungkapkan bisa lebih efektif jika diungkapkan dengan fluktuasi yang sesuai dengan emosi yang sedang dirasakan serta tidak berbicara dengan monoton karena emosi yang fluktuatif. Latency of response menggambarkan jeda durasi antara akhir ucapan seseorang sampai waktu orang lain dalam merespon pembicaraan. Faktanya dengan jeda waktu yang sedikit sebelum menjawab, umumnya dipandang lebih asertif dibandingkan dengan individu yang tidak terdapat jeda dalam merespon pembicaraan. Adapun nonverbal behavior terdiri dari beberapa komponen, yaitu: kontak mata, ekspresi mimik, jarak fisik, sikap tubuh, serta gestur tubuh.

Menurut Aziz (dalam Fuadah, 2013) orang Sunda sangat berhati-hati dan khawatir apabila ungkapan yang dipakainya melukai perasaan lawan bicaranya. Dalam kebudayaan Sunda terdapat banyak falsafah yang mengatur cara berkomunikasi seperti "Leuir biwir hawara pikir" yang artinya dalam setiap pembicaraan harus dipikirkan terlebih dahulu supaya tidak terjadi kesalahan dalam menangkap maksud dari komunikan, selain itu ada istilah "Ulah pagirang-girang tampian” yang artinya jangan membuat orang lain merasa sakit hati.

Menurut Warnaen (dalam Setiawan, 2017) masyarakat Sunda memiliki pandangan bahwa keharmonisan, kerukunan, kedamaian dan ketenteraman menjadi hal paling yang harus dilaksanakan dalam kehidupan bermasyarakat. Warnaen juga menyebutkan, sebisa mungkin mengelak dari kegaduhan, lebih baik diam dan meredamnya, memendam rasa (pundung) daripada menolak dengan agresi atau pertikaian, sehingga terkesan seolah tidak memiliki keberanian; pertikaian atau perlawanan merupakan pilihan yang paling akhir (Setiawan, 2017). 
Berdasarkan penelitian yang dilakukan Novianti dan Tjalla (2008) bahwa anak dari orang tua yang berasal dari suku Sunda kurang mampu berkomunikasi secara asertif karena mereka cemas ketika mengabaikan sisi kebudayaannya. Menurut Rosidi (2010) masyarakat Sunda memiliki keinginan untuk dipandang baik oleh orang lain dan ingin terpakai oleh orang lain. Hal ini disebabkan karena masyarakat Sunda menjadi bangsa yang terjajah sejak lama dan mempunyai mental agar terpakai oleh majikan atau atasan. Selain hal itu, masyarakat Sunda juga memiliki kebiasaan memberikan rasa nyaman dan tenang terhadap orang lain, hal ini membuat masyarakat memilih untuk menyembunyikan perasaannya daripada harus mengungkapkan supaya tidak menyinggung perasaan orang lain dan sulit berkomunikasi secara asertif.

Fenomena ini terjadi pada berbagai kalangan, termasuk juga mahasiswa. Peneliti berasumsi bahwa meskipun dalam lingkungan kampus terjadi akulturasi budaya, hal ini tidak mengakibatkan kemampuan komunikasi mahasiswa menjadi asertif. Scott (2006) mendefinisikan asertif sebagai bentuk tingkah laku interpersonal yang terdiri dari komunikasi secara langsung, terbuka dan jujur yang menunjukkan pertimbangan dan penghormatan terhadap individu lain. Dalam komunikasi asertif ini pembicara harus bisa menyampaikan inti yang diharapkan sekaligus mampu mempertimbangkan kenyamanan perasaan dari lawan bicara.

Berdasarkan survei awal yang dilakukan, ditemukan bahwa mahasiswa Sunda belum mampu melakukan komunikasi secara asertif terutama dalam menyanggah dan mengemukakan pendapat pribadi. Hal ini disebabkan rasa malu dan ketakutan untuk tidak dihargai oleh lingkungan sosialnya. Perilaku tersebut muncul sejak kecil sehingga tidak disadari alasan munculnya perilaku tersebut. Rathus dan Nevid (dalam Andayani \& Mardianto, 2015) menyatakan bahwa kebudayaan menjadi salah satu faktor yang memengaruhi kemampuan asertif. Hasil penelitian Suryanto (dalam Novianti \& Tjalla, 2008) menyebutkan bahwa faktor pembentuk identitas etnik adalah hasil proses sosialisasi dalam lingkungan masyarakat yang disesuaikan dengan nilai-nilai etnik yang ada, sehingga seiring dengan perkembangan fisik dan kognitifnya akan memahami perbedaan antara dirinya dengan yang lain.

Berdasarkan paparan di atas, penelitian ini bertujuan untuk mengetahui bagaimana identitas etnik yang dimiliki mahasiswa Sunda memberikan pengaruh terhadap kemampuan berkomunikasi secara asertif. Karena perkembangan zaman yang menuntut keterbukaan informasi ini mengharuskan semua kalangan khususnya mahasiswa untuk mampu berkomunikasi secara asertif.

\section{Metode}

Penelitian ini merupakan penelitian kuantitatif korelasional dengan menggunakan desain analisis regresi linier sederhana. Desain korelasional ini adalah untuk melihat terdapat pengaruh atau tidak pada variabel yang diteliti. Variabel yang dikritisi pada penelitian ini adalah variabel identitas etnik sebagai variabel $\mathrm{X}$ dan variabel asertivitas sebagai variabel $\mathrm{Y}$. Populasi dalam penelitian ini yaitu mahasiswa Universitas Islam Negeri Sunan Gunung Djati Bandung yang beretnik Sunda dengan jumlah populasi yang tidak diketahui. Adapun yang menjadi sampel penelitian sebanyak 82 orang (30 laki-laki; 52 perempuan) yang diperoleh melalui teknik accidental sampling.

Instrumen menggunakan skala likert. Alat ukur yang digunakan untuk mengukur kualitas identitas etnik diadaptasi dari skala Multigroup Ethnic Identity Measure-Revised (MEIM-R) Phinney dan Ong (2007). Skala tersebut mengukur dua aspek yaitu exploration dan commitment, dan masing-masing aspek terdiri dari 3 item. Skor pada masing-masing item bergerak dari skor 1 sampai dengan 4 . Alat ukur yang digunakan untuk mengukur asertivitas disusun berdasarkan lima aspek asertivitas menurut Alberti dan Emmons (2017) dengan jumlah item sebanyak 25 item. 
Tabel 1

Hasil Uji Validitas Skala Identitas Etnik

\begin{tabular}{ccc}
\hline \multicolumn{1}{c}{ Aspek } & $\begin{array}{c}\text { Koefisien } \\
\text { Korelasi }\end{array}$ & Kriteria \\
\hline Exploration & .945 & Sangat Tinggi \\
Commitment & .985 & Sangat Tinggi \\
\hline
\end{tabular}

Tabel 2

Hasil Uji Validitas Skala Asertivitas

\begin{tabular}{lcc}
\hline \multicolumn{1}{c}{ Aspek } & $\begin{array}{c}\text { Koefisien } \\
\text { Korelasi }\end{array}$ & Kriteria \\
\hline $\begin{array}{l}\text { Bebas bertindak } \\
\text { menurut kehendak } \\
\text { pribadi }\end{array}$ & .677 & Tinggi \\
$\begin{array}{l}\text { Mengekspresikan } \\
\text { dengan perasaan }\end{array}$ & .735 & Tinggi \\
$\begin{array}{l}\text { jujur dan nyaman } \\
\text { Membela diri sendiri }\end{array}$ & .644 & Tinggi \\
$\begin{array}{l}\text { Menerapkan hak-hak } \\
\text { pribadi }\end{array}$ & .643 & Tinggi \\
$\begin{array}{l}\text { Mempromosikan } \\
\text { kesetaraan dan tidak } \\
\text { menampik hak orang }\end{array}$ & .810 & Sangat \\
lain & & Tinggi \\
\hline
\end{tabular}

Uji validitas dilakukan dengan menggunakan formula pearson corelation. Sedangkan dalam menerjemahkan koefisien validitas menggunakan pengkelasan dari Guilford (dalam Azwar, 2013; Ramdani, 2018). Hasil perhitungan uji validitas pada kedua alat ukur menunjukkan nilai validitas yang berada pada kategori validitas sangat tinggi untuk kedua aspek skala identitas etnik, serta kategori tinggi hingga sangat tinggi untuk aspek-aspek skala asertivitas sebagaimana disajikan pada tabel 1 dan tabel 2.

Adapun hasil perhitungan reliabilitas menggunakan alpha cronbach, nilai koefisien dari skala identitas etnik yaitu .842 termasuk kategori sangat tinggi dan skala asertivitas sebesar .714 juga termasuk ke dalam kategori tinggi. Setelah diketahui validitas dan reliabilitas masing-masing skala maka dilanjutkan dengan pengambilan data dan selanjutnya pengolahan data. Dimulai dengan analisis deskriptif, kemudian uji asumsi klasik mencakup uji normalitas, uji heteroskedastisitas, uji auto korelasi, dan uji linieritas, serta analisis inferensial menggunakan regresi linier sederhana.
Hasil

\section{Analisis Deskriptif}

Analisis deskriptif identitas etnik. Berdasarkan hasil perhitungan variabel identitas etnik maka didapat mean sebesar 17.70. Maka subjek yang memiliki skor $\geq 18$ dianggap memiliki identitas etnik yang tinggi. Sedangkan subjek yang memiliki total skor <18 dianggap memiliki identitas etnik yang rendah. Standar deviasi sebesar 3.085 dengan nilai minimum 8 dan nilai maksimum 24. Hasil responden yang termasuk ke dalam kategori tinggi dan rendah dapat dilihat pada tabel 3 .

Analisis deskriptif asertivitas. Berdasarkan hasil perhitungan variabel asertivitas maka didapat mean sebesar 65.36. Maka subjek yang memiliki skor $\geq 65$ dianggap memiliki identitas etnik yang tinggi. Sedangkan subjek yang memiliki total skor <65 dianggap memiliki identitas etnik yang rendah. Standar deviasi sebesar 6.574 dengan nilai minimum 54 dan nilai maximum 85 . Hasil analisis deskriptif asertivitas bisa dilihat pada tabel 4 .

\section{Uji Asumsi Klasik}

Uji Normalitas. Berdasarkan hasil perhitungan menggunakan formula One Sample Kolmogorov Smirnov diperoleh nilai .726. Sehingga dapat diambil kesimpulan bahwa data berdistribusi normal karena .726>.05.

Tabel 3

Kategori Variabel Identitas Etnik

\begin{tabular}{lccc}
\hline & & \multicolumn{2}{c}{ Proporsi } \\
\cline { 3 - 4 } Kategori & Skor & $\Sigma$ & $\%$ \\
\hline Tinggi & $\mathrm{X} \geq 18$ & 48 & 58.54 \\
Rendah & $\mathrm{X}<18$ & 34 & 41.46 \\
\hline
\end{tabular}

Tabel 4

Kategori Variabel Asertivitas

\begin{tabular}{llcc}
\hline & & \multicolumn{2}{c}{ Proporsi } \\
\cline { 3 - 4 } Kategori & Skor & $\Sigma$ & $\%$ \\
\hline Tinggi & $\mathrm{X} \geq 65$ & 42 & 51.2 \\
Rendah & $\mathrm{X}<65$ & 40 & 48.8 \\
\hline
\end{tabular}




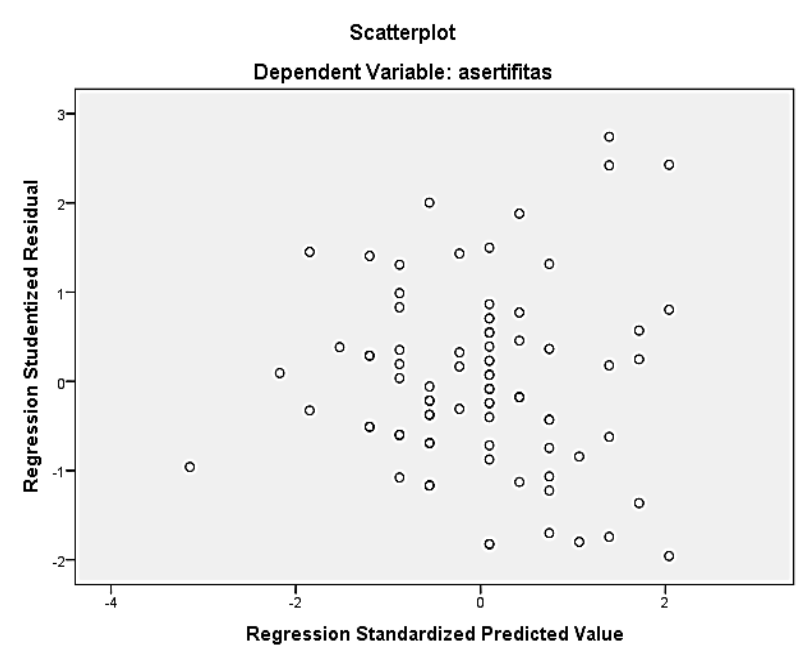

Gambar 1. Scatterplots Heteroskedastisitas

Uji Heteroskedastisitas. Berdasarkan perhitungan menggunakan Scatterplots sebaran titik-titik berada di bawah dan di atas 0 pada sumbu Y, sehingga memenuhi persayaratan dalam uji heteroskedastisitas. Untuk lebih jelasnya dapat dilihat di gambar 1 .

Uji Autokorelasi. Berdasarkan hasil perhitungan menggunakan formula Durbin Watson diperoleh $\mathrm{DW}=1.739$. Dilanjutkan dengan melihat tabel DW, didapatkan DU= 1.66569 dan $\mathrm{DL}=1.61639$. Maka dapat disimpulkan tidak terdapat autokorelasi karena $1.665<1.739<2.334$ atau DU<DW<4-DU.

Uji Linieritas. Berdasarkan perhitungan diperoleh nilai signifikansi >.05 yaitu .626 . Selain berdasarkan nilai signifikansi dengan melihat nilai $\mathrm{F}_{\text {hitung }}<\mathrm{F}_{\text {tabel }}$ dapat membuktikan bahwa data bersifat linier. $F_{\text {hitung }}$ sebesar .831 dan untuk melihat $F_{\text {tabel }}$ dengan $\alpha=0.5, \mathrm{df} 1=13$, df2 $=67$ sebesar 1.87 .

Berdasarkan uji asumsi klasik yang sudah dilakukan, semua uji memenuhi kriteria dan dapat dilanjutkan untuk melakukan analisis inferensial menggunakan uji regresi linier sederhana.

\section{Analisis Inferensial}

Dalam analisis yang pertama untuk mengetahui terdapat pengaruh atau tidak dari variabel identitas etnik terhadap asertivitas. Diperoleh nilai signifikansi .012 artinya terdapat pengaruh identitas etnik terhadap asertivitas karena nilai signifikansi <.05. Selain melihat hasil nilai signifikansi juga dapat melihat nilai $\mathrm{F}_{\text {hitung. Berdasarkan tabel 5, }}$ diketahui $\mathrm{F}_{\text {hitung }} 6.544$ dan melihat $\mathrm{F}_{\text {tabel }}$ dengan df $1=1$, df $2=80$ dan $\alpha=.05$ yaitu 3.96. Maka

Tabel 5

Hasil Uji Hipotesis

\begin{tabular}{|c|c|c|c|c|c|c|}
\hline & Model & Sum of Squares & $d f$ & Mean Square & $F$ & Sig. \\
\hline \multirow{3}{*}{1} & Regression & 264.737 & 1 & 264.737 & 6.544 & $.012^{\mathrm{b}}$ \\
\hline & Residual & 3236.288 & 80 & 40.454 & & \\
\hline & Total & 3501.024 & 81 & & & \\
\hline
\end{tabular}

a. Dependent Variable: asertivitas

b. Predictors: (Constant), ethnic identity

Tabel 6

Hasil Uji Koefisien Determinasi

\begin{tabular}{ccccc}
\hline Model & $\mathrm{R}$ & $\mathrm{R}$ Square & Adjusted $R$ Square & Std. Error of the Estimate \\
\hline 1 & $.275^{\mathrm{a}}$ & .076 & .064 & 6.360 \\
\hline
\end{tabular}

a. Predictors: (Constant), ethnic identity

Tabel 7

Hasil Uji Koefisien Regresi

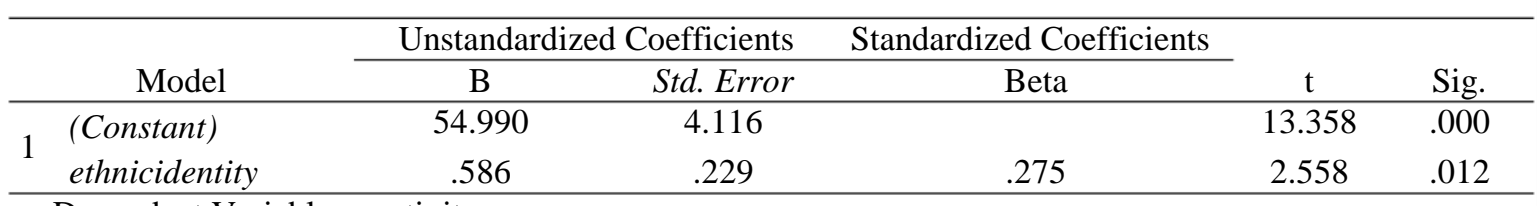

a. Dependent Variable: asertivitas 
$\mathrm{F}_{\text {hitung }}>\mathrm{F}_{\text {tabel }}$ artinya identitas etnik memengaruhi asertivitas mahasiswa Suku Sunda. Selanjutnya dilakukan uji koefisien determinasi untuk melihat pengaruh variabel dependen terhadap variabel independen. Berdasarkan tabel 6 diperoleh $R_{\text {square }} .076$. Dapat diketahui bahwa pengaruh identitas etnik terhadap asertivitas pada mahasiswa suku Sunda di UIN Sunan Gunung Djati sebesar $7.6 \%$ dan selebihnya dipengaruhi oleh faktor lain yang tidak diteliti pada penelitian ini.

Berdasarkan tabel 7 diperoleh konstanta sebesar 54.990 dan koefisien regresi .586. Maka diperoleh persamaan regresi linier sederhana $(\mathrm{Y}=54.990+.586 \mathrm{X})$. Dengan persamaan regresi tersebut menunjukkan bahwa apabila identitas etnik bernilai 0 maka nilai asertivitasnya 54.990. Selanjutnya dengan koefisien regresi .586 menunjukkan bahwa setiap identitas etnik individu meningkat $1 \%$ maka asertivitasnya meningkat .586 .

Selanjutnya dilakukan uji koefisien regresi untuk melihat kualitas pengaruh identitas etnik terhadap asertivitas mahasiswa suku Sunda. Hasil perhitungannya disajikan pada tabel 7 . Dapat disimpulkan bahwa identitas etnik memberikan pengaruh positif terhadap asertivitas mahasiswa suku Sunda.

Sebagai data penunjang, dalam penelitian ini dihitung pula perbedaan jenis kelamin terkait dengan koefisien determinasi dari identitas etnik terhadap asertivitas. Ditemukan bahwa pada responden perempuan sebesar $1.1 \%$ sedangkan pada responden laki-laki sebesar 9.2\% sebagaimana disajikan pada tabel 8 dan tabel 9.

Tabel 8

Hasil Uji Koefisien Determinasi Subjek Perempuan

\begin{tabular}{cccc}
\hline $\mathrm{R}$ & $\begin{array}{c}\mathrm{R} \\
\text { Square }\end{array}$ & $\begin{array}{c}\text { Adjusted } \mathrm{R} \\
\text { Square }\end{array}$ & $\begin{array}{c}\text { Std. Error of } \\
\text { the Estimate }\end{array}$ \\
\hline .103 & .011 & -.003 & 6.868 \\
\hline
\end{tabular}

The independent variable is ethnic identity.

Tabel 9

Hasil Uji Koefisien Determinasi Subjek Laki-laki

\begin{tabular}{cccc}
\hline $\mathrm{R}$ & $\begin{array}{c}\mathrm{R} \\
\text { Square }\end{array}$ & $\begin{array}{c}\text { Adjusted } \mathrm{R} \\
\text { Square }\end{array}$ & $\begin{array}{c}\text { Std. Error of } \\
\text { the Estimate }\end{array}$ \\
\hline .303 & .092 & .054 & 8.710 \\
\hline \multicolumn{3}{l}{ The independent variable is ethnic identity. }
\end{tabular}

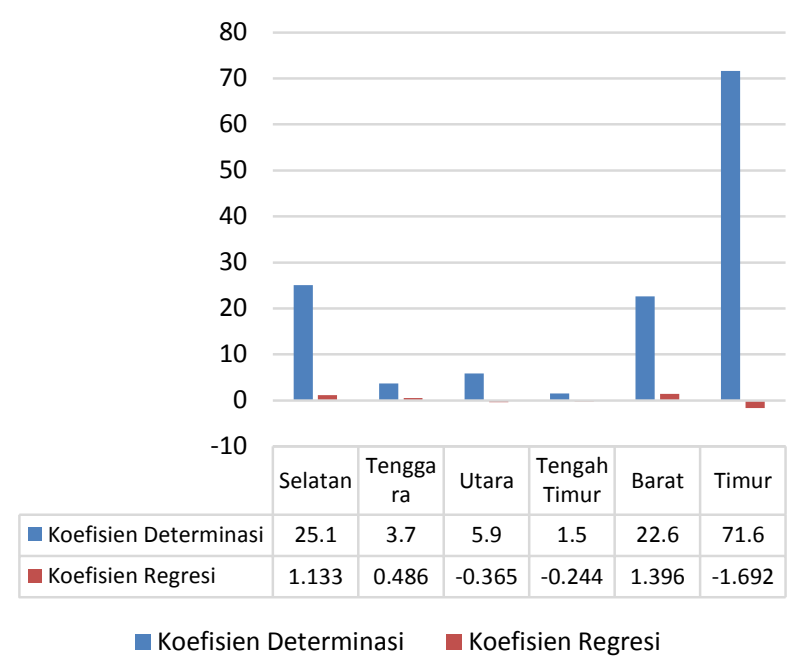

Gambar 2. Hasil uji berdasarkan asal wewengkon

Pada gambar 2 dapat dilihat penelitian ini juga menunjukkan bahwa daerah yang berbatasan langsung dengan wilayah yang dikuasai oleh Mataram seperti Cirebon yang merupakan wewengkon Timur Laut daerah Sunda bahwa identitas etnik memberikan pengaruh yang sangat signifikan yaitu $71.6 \%$ terhadap kemampuan asertivitasnya dengan koefisien regresi -1.692. Hal ini disebabkan pengaruh yang diberikan oleh budaya Jawa lebih dominan dibandingkan dengan pengaruh yang berasal dari budaya Sunda. Berbeda halnya dengan yang terjadi di wewengkon Barat yang meliputi Banten. Koefisien regresinya menunjukkan bahwa setiap bertambahnya identitas etnik seseorang maka kemampuan asertivitasnya bertambah sebesar 1.396 .

\section{Diskusi}

Hipotesis awal peneliti bahwa identitas etnik memberikan pengaruh negatif terhadap asertivitas mahasiswa suku Sunda disebabkan masyarakat Sunda yang dikenal kurang asertif. Hal ini terkait dengan banyaknya aturan seperti "Leuir biwir hawara pikir" yang artinya dalam setiap pembicaraan harus dipikirkan terlebih dahulu supaya tidak terjadi kesalahan dalam menangkap maksud pembicaraan. Terdapat pula aturan "Ulah pagirang-girang tampian" artinya jangan membuat orang sakit hati dengan 
perkataan kita. Menurut Novianti dan Tjalla (2015) anak dari orang tua yang berasal dari suku Sunda kurang mampu berkomunikasi secara asertif karena mereka merasa cemas apabila mengabaikan sisi kebudayaannya. Penelitian yang dilakukan Novianti dan Tjalla ini dilakukan kepada anak usia remaja di lingkungan sekolah SMA. Maka dari hasil penelitian tersebut bahwa dalam budaya Sunda terdapat aturan untuk tidak berkomunikasi secara asertif.

Aturan tidak berkomunikasi secara asertif ini disebabkan adanya undak usuk basa. Adanya undak usuk basa bertujuan untuk saling menghargai dan menghormati antar sesama. Hal ini tentu saja diiringi dengan raut muka, gaya pengucapan serta gerakan tubuh yang sopan. Rosidi (2010) membagi undak usuk bahasa Sunda ke dalam 4 tingkatan, yaitu kasar, sedeng, lemes, dan lemes pisan. Namun terkadang ada cara pengucapan yang kasar pisan yang biasa disebutkan untuk perilaku yang ditunjukkan oleh binatang. Karena tingkatan bahasa itu, masyarakat Sunda sangat memperhatikan gaya komunikasi antar sesamanya.

Penggunaan undak usuk basa ini harus memperhatikan usia lawan bicara. Menurut Ekadjati (1995) terdapat enam kategori usia lawan bicara tersebut, yaitu: 1) orok (bayi) yang berusia sejak lahir sampai usia 12 bulan; 2) budak (anak-anak) yang berusia 1-5 tahun; 3) bujang atau jajaka bagi laki-laki dan lajang, mojang atau parawan bagi perempuan. Usianya berkisar antara 16-25 tahun; 4) sawawa (dewasa) yang berusia antara 26-40 tahun; 5) tengah tuwuh (madya) yang berusia 41-50 tahun; 6) kolot (tua) yang berumur 51 tahun. Kategori usia ini dapat berbeda-beda pada setiap daerah, kelompok sosial serta status orang bersangkutan. Dengan adanya aturan inilah yang memungkinkan masyarakat suku Sunda kurang dapat berkomunikasi secara asertif.

Dalam penelitian ini, hasilnya bahwa identitas etnik memberikan pengaruh positif terhadap asertivitas mahasiswa suku Sunda. Artinya, undak usuk basa yang menjadi aturan dalam berkomunikasi tidak digunakan dengan baik. Menurut Setiawan (2017) bahwa pada awalnya masyarakat Sunda adalah manusia yang berkomunikasi tanpa aturan yang membuatnya asertif, namun karena terjajah berabad-abad lamanya oleh masyarakat Jawa sehingga masyarakat Sunda menjadi sangat memperhatikan undak usuk basa yang mengikat dan dapat menjadi pembatas untuk tidak berbicara sesuai dengan keinginan.

Kenyataannya, undak usuk basa baru meresap ke tataran Sunda pada abad ke-17. Pada saat beberapa bagian wilayah Sunda berada di bawah dominasi Mataram, terutama di wilayah Priangan Ciamis, Tasikmalaya, Garut, Bandung, Sumedang dan Cianjur. Seperti yang telah dijelaskan Ekadjati (1995) bahwa wilayah Sunda awalnya hanya berdasarkan pada dua wilayah yang independen, yaitu Sumedang dan Galuh. Pada 1595 wilayah Galuh dikuasai oleh Mataram di bawah pemerintahan Panembahan Senopati. Setelah kekuasaan Mataram beralih ke tangan Sultan Agung, Sumedang juga menyerahkan diri kepada kerajaan Mataram.

Akibat dari dominasi Mataram di wilayah Sunda yang dirasakan salah satunya adalah terdapat tingkatan sosial melalui bahasa. Bahasa Sunda sebelumnya tidak menggunakan tingkatan bahasa, dengan perlahan-perlahan mulai menggunakan tingkatan yaitu halus, sedang dan kasar yang diambil dari tingkatan bahasa Jawa yang mengaplikasikan bahasa kasar/ngoko dan bahasa halus/ kromo. Hierarki bahasa yang digunakan di pusat-pusat kekuasaan Mataram di Jawa mengaplikasikan tingkatan bahasa strata krama inggil-krama mady-ngoko yang diadaptasi ke dalam bahasa Sunda menjadi lemes, sedeng, dan kasar. Sehingga dapat diambil kesimpulan bahwa adanya hierarki/ pengkelasan bahasa pada etnik Sunda terjadi pasca abad ke-17 ketika wilayah Sunda ditundukkan Mataram dan memengaruhi cara komunikasi pada kebiasaan orang Sunda.

Berdasarkan penelitian ini juga menunjukkan bahwa daerah yang berbatasan langsung dengan wilayah yang dikuasai oleh Mataram seperti Cirebon yang merupakan 
wewengkon Timur Laut daerah Sunda bahwa identitas etnik memberikan pengaruh yang sangat signifikan. Hal ini disebabkan pengaruh yang diberikan oleh budaya Jawa lebih dominan dibandingkan dengan pengaruh yang berasal dari budaya Sunda. Berbeda halnya dengan yang terjadi di wewengkon Barat yang meliputi Banten. Hal ini menunjukkan memang pada dasarnya masyarakat Sunda adalah masyarakat yang tidak menggunakan undak usuk basa yang mengakibatkan masyarakat Sunda merupakan masyarakat yang dapat berkomunikasi secara asertif.

Selain itu, Kota Bandung sebagai ibukota provinsi terpadat se-Indonesia membuat proses akulturasi budaya menjadi hal yang biasa ditemui di kota ini. Oleh karenanya, meskipun identitas etnik yang dimiliki mahasiswa tergolong tinggi, tetap saja karena adanya akulturasi budaya yang semakin hari semakin banyak terjadi membuat banyak nilai-nilai budaya Sunda terutama yang mengatur cara berkomunikasi mulai ditinggalkan.

Dalam budaya Sunda terdapat beragam dialek atau yang biasa disebut sebagai basa wewengkon. Adapun dialek atau wewengkon tersebut dibagi menjadi 6 bagian, yaitu dialek Barat yang meliputi seluruh kabupaten dan kota di Provinsi Banten; dialek Utara yang meliputi Kabupaten Bogor, Karawang, Subang, Purwakarta, Bekasi, Kota Bogor dan Kota Bekasi; dialek Selatan (priangan) meliputi Bandung Raya, Cianjur, Sukabumi dan Sumedang; dialek Tengah Timur meliputi Majalengka dan bagian Selatan Kabupaten Indramayu; dialek Timur Laut meliputi Kuningan, bagian Selatan Cirebon, dan bagian Barat Kabupaten Brebes; serta dialek Tenggara meliputi Ciamis, Garut, Pangandaran, Tasikmalaya, Banjar dan Cilacap.

Perbedaan dialek atau wewengkon ini disebabkan adanya akulturasi dengan budaya yang lain. Wewengkon yang terbagi menjadi 6 bagian ini menunjukkan dialek bahasa yang berbeda dan menimbulkan pola-pola yang berbeda baik dalam cara berkomunikasi hingga cara bersikap. Misalnya wewengkon Barat dengan wewengkon Priangan, pada wewengkon
Barat tidak terdapat undak usuk basa, tetapi pada wewengkon Priangan undak usuk basa merupakan panduan berbahasa yang harus digunakan masyarakatnya. Hal ini menunjukkan bahwa dengan adanya perbedaan wewengkon dalam Budaya Sunda merupakan nilai tambah dari kekayaan budaya Sunda itu sendiri.

Usia juga memberikan pengaruh terhadap gaya komunikasi pada mahasiswa. Menurut Ekadjati (1995) pergaulan dalam usia muda/ mudi ini lebih banyak beragam dan dinamis, serta ruang lingkupnya lebih luas dan kompleks daripada pergaulan di kalangan anak-anak. Hal ini menguatkan bahwa responden dalam penelitian yang termasuk ke dalam kategori jajaka/mojang mengalami banyak perubahan dalam identitas etniknya disebabkan pergaulan yang luas dengan berbagai macam individu yang berbeda-beda dari segi asal etnik, budaya dan aturan dalam berperilaku. Sehingga undak usuk basa yang menjadi aturan dalam berkomunikasi pada budaya Sunda menjadi terkikis demi menyesuaikan diri dengan pola komunikasi yang berlaku pada multietnik.

Selain hal di atas, semakin majunya tingkat pendidikan yang didapatkan oleh masyarakat Sunda dirasakan menjadi faktor pendorong yang cukup kuat dalam meningkatkan kemampuan berkomunikasi secara asertif. Pernyataan ini sesuai dengan pendapat yang dikemukakan oleh Rathus dan Nevid (dalam Andayani \& Mardianto, 2015) yang menjelaskan tentang 6 faktor yang memengaruhi perkembangan perilaku asertif yaitu jenis kelamin, self-esteem, kebudayaan, tingkat pendidikan, tipe kepribadian dan situasi tertentu lingkungan sekitarnya.

Berkaitan dengan faktor jenis kelamin, perempuan pada umumnya lebih sulit asertif seperti mengungkapkan perasaan dan pikiran dibandingkan dengan laki-laki. Dalam penelitian ini koefisien determinasi dari identitas etnik terhadap asertivitas pada responden perempuan ditemukan lebih kecil dibandingkan dengan responden laki-laki.

Dalam budaya Sunda dikenal istilah "Awewe dulang tinande" serta istilah "Awewe 
pondok lengkah", yang artinya perempuan tidak diperkenankan untuk keluar jauh dari rumah dan harus patuh terhadap semua permintaan laki-laki. Pakem budaya ini menjadi aturan bahwa perempuan hanya diperkenankan untuk mengurusi urusan domestik rumah tangga atau dikenal dengan istilah "tilu ur". "Tilu ur" ini merupakan kepanjangan dari "sumur", "dapur", dan "kasur". "Sumur" berarti tugas perempuan adalah mencuci, "dapur" berarti tugas perempuan adalah memasak, dan "kasur" berarti tugas perempuan adalah melayani kebutuhan biologis suami. Sedangkan urusan yang termasuk ranah publik merupakan urusan laki-laki.

Apabila ada perempuan yang ikut terlibat dalam ranah yang menjadi urusan laki-laki, perempuan tersebut disebut sebagai "awewe jalingkak" yang artinya perempuan tomboy. Dalam budaya Sunda "awewe jalingkak" ini berkonotasi negatif, sehingga perempuan Sunda berusaha untuk menjaga jarak dari ranah publik supaya tidak disebut sebagai "awewe jalingkak".

Dari aturan inilah yang membuat kemampuan komunikasi yang dimiliki perempuan Sunda tidak sebaik kemampuan berkomunikasi pada laki-laki Sunda. Padahal dalam budaya Sunda buhun (kuno), kedudukan antara lakilaki dan perempuan adalah sama, bahkan perempuan lebih diutamakan. Adanya istilah "Indung tunggul rahayu, bapa tangkal darajat" yang artinya segala keselamatan, kebahagiaan dan kesejahteraan adalah doa ibu dan ayah. Kemudian ada istilah "Indung nu ngakandung bapa nu ngayuga", artinya tidak akan ada anak tanpa kasih sayang ibu dan ayah. Dari kedua istilah tersebut posisi "indung" sebagai perempuan lebih diutamakan dibandingkan "bapa" atau laki-laki. Nampak-nya pergeseran ini juga merupakan dampak yang ditimbulkan dari adanya penjajahan dari Mataram dan Belanda, sehingga suku Sunda yang awalnya merupakan masyarakat legaliter menjadi masyarakat feodal yang patriarki.

Pada faktor self-esteem keyakinan seseorang ikut memberikan pengaruh terhadap kemampuan untuk beradaptasi dalam domain- nya (Kawamoto, 2020). Individu dengan keyakinan diri yang tinggi memiliki kekhawatiran sosial yang rendah sehingga mampu mengutarakan persepsi serta emosi dengan tidak memadaratkan orang lain dan diri sendiri. Dalam lingkup kebudayaan, intervensi sosial menentukan aturan-aturan berperilaku, yang mana aturan tersebut berdasarkan usia, jenis kelamin dan status sosial seseorang (Tang, Ma, Zhou, Shi, \& Ma, 2019).

Aspek jenjang pendidikan memberikan pengaruh terhadap luasnya wawasan yang dimiliki individu tersebut (Tang dkk., 2019). Artinya jenjang pendidikan individu yang rendah membuat cakupan wawasan berpikirnya juga rendah. Begitupun sebaliknya, individu dengan jenjang pendidikan yang tinggi akan memiliki keluasan wawasan dalam berpikir.

Berkaitan dengan faktor tipe kepribadian maksudnya adalah cara merespon suatu stimulus antara satu individu dengan individu lainnya akan berbeda. Hal ini dipengaruhi oleh tipe kepribadian seperti apa yang dimiliki individu tersebut. Terakhir, faktor situasi tertentu lingkungan sekitarnya akan menentukan pandangan individu atas keadaan dan suasana atau kondisi dalam arti luas, misalnya posisi dalam perusahaan antara pemilik dan pegawai (Van Heel dkk., 2019).

Berdasarkan penelitian ini memperkuat bahwa responden yang berasal dari perguruan tinggi memang memiliki kecenderungan yang baik untuk berkomunikasi secara asertif (Andayani \& Mardianto, 2015). Sehingga meskipun identitas etnik yang dimiliki tergolong ke dalam kategori baik, kemampuan berkomunikasi secara asertif pun baik karena dalam situasi dan lingkungan sekitarnya menuntut untuk dapat berkomunikasi secara asertif.

Berdasarkan penelitian yang dilakukan Jaenudin dan Tahrir (2019) bahwa nilai-nilai dan norma-norma yang telah melekat pada masyarakat Sunda senantiasa tumbuh dan berkembang seiring dengan laju pembangunan. Sehingga nilai-nilai budaya Sunda menjadi perekat keselarasan dan stabilitas sosial. 
Berdasarkan pemaparan di atas, peneliti dapat menarik dua simpulan yang memengaruhi kemampuan asertivitas mahasiswa yang berasal dari etnik Sunda tetap tinggi. Simpulan pertama adalah aturan dalam berkomunikasi yang dianut oleh masyarakat Sunda yaitu "undak usuk basa", ternyata bukan berasal dari budaya Sunda asli. Melainkan hasil dari politik feodalisme kerajaan Mataram yang beretnik Jawa. Sehingga aturan "undak usuk basa" tidak dipakai secara menyeluruh oleh masyarakat Sunda. Pada dasarnya masyarakat Sunda adalah masyarakat yang tidak memiliki aturan yang mengikat dan ketat dengan siapa kita berbicara, memperhatikan usia lawan bicara dan bagaimana tingkatan dalam kedudukan sosial.

Simpulan kedua adalah tingkat pendidikan yang dimiliki responden termasuk pada jenjang perguruan tinggi, membuat situasi dan tuntutan lingkungan mengharuskan untuk dapat berkomunikasi secara asertif. Dalam lingkungan kampus, budaya yang berlaku adalah budaya legaliter. Sehingga bukan hanya karena keluasan wawasan yang menjadi penyebab responden mampu berkomunikasi secara luas, namun karena didikan legaliter yang berlaku di lingkungan kampus membuat mahasiswa dapat dengan bebas mengungkapkan pendapat dan perasaannya secara asertif tanpa takut membentur aturan yang membelenggu kebebasan berkomunikasi.

Selain kedua simpulan di atas, adanya perkembangan zaman yang mengakibatkan proses akulturasi budaya berjalan dengan cepat membuat kemampuan untuk berkomunikasi secara asertif sangat dibutuhkan. Sehingga identitas etnik memberikan pengaruh positif terhadap kemampuan asertivitas pada mahasiswa suku Sunda yang berkuliah di UIN Sunan Gunung Djati Bandung.

\section{Simpulan}

Berdasarkan penelitian ini didapatkan simpulan bahwa identitas etnik berpengaruh positif terhadap asertivitas mahasiswa suku Sunda. Pengaruh identitas etnik terhadap asertivitas sebesar 7.6\%. Beberapa hal yang turut memperkuat diantaranya bahwa masyarakat Sunda pada dasarnya tidak memiliki aturan yang mengikat secara ketat dengan siapa berbicara dalam kaitan usia ataupun tingkat kedudukan sosial lawan bicara; tuntutan situasi di lingkungan kampus membuat mahasiswa dapat dengan bebas mengungkapkan pendapat dan perasaannya secara asertif; serta terjadinya akulturasi budaya yang berjalan cepat menuntut mahasiswa untuk menyesuaikan diri dengan pola komunikasi yang berlaku pada multietnik.

\section{Referensi}

Alberti, R. E., \& Emmons, M. L. (2017). Your perfect right tenth edition: Assertiveness and equality in your life and relationship. Oakland: New Harbinger Publication Inc.

Andayani, F. T., \& Mardianto. (2015). Perbedaan asertivitas antara mahasiswa etnik minang dan etnis batak. Jurnal RAP UNP, 6(1), 33-34.

Arandia, G., Sotres-Alvarez, D., Siega-Riz, A. M., Arredondo, E. M., Carnethon, M. R., Delamater, A. M., \& Perreira, K. M. (2018). Associations between acculturation, ethnic identity, and diet quality among U.S. Hispanic/Latino Youth: Findings from the HCHS/SOL Youth Study. Appetite, 129, 25-36. doi.org/10.1016/j.appet.2018.06.017

Azwar, S. (2013). Metode penelitian. Yogyakarta: Pustaka Pelajar.

Badan Pusat Statistik. (2011). Kewarganegaraan, Suku Bangsa, Agama dan Bahasa Sehari-hari Penduduk Indonesia Hasil Sensus Penduduk 2010. ISBN 9789790644175.

Bennett, W. G. (2015). Assimilation, dissimilation, and surface correspondence in Sundanese. Natural Language and Linguistic Theory, 33(2), 371-415. doi.org/10.1007/s11049-014-9268-2

Bigman, C. A., Mello, S., Sanders-Jackson, A., \& Tan, A. S. L. (2018). Assertive communication about others' smoking and vaping in public venues: Results from a 
National Survey of US adults. Addictive Behaviors, 87(February), 196-199. doi.org/10.1016/j.addbeh.2018.07.015

Dimitrova, R., Ferrer-Wreder, L., \& Trost, K. (2015). Intergenerational transmission of ethnic identity and life satisfaction of Roma minority adolescents and their parents. Journal of Adolescence, 45, 296306.

doi.org/10.1016/j.adolescence.2015.10.014

Ekadjati, E. S. (1995). Kebudayaan sunda (suatu pendekatan sejarah). Jakarta: Pustaka Jaya.

Fathurroja, A., Mumtazah, H., Rosiana, R., Pudoli, S. B. M., \& Fridayanti, F. (2018). Gambaran identitas etnik remaja Suku Jawa dan Sunda. Jurnal Psikologi Islam dan Budaya, 1(2), 107-112. doi.org/10.15575/jpib.v1i2.3412

Fisher, S., Zapolski, T. C. B., Sheehan, C., \& Barnes-Najor, J. (2017). Pathway of protection: Ethnic identity, self-esteem, and substance use among multiracial youth. Addictive Behaviors, 72, 27-32. doi.org/10.1016/j.addbeh.2017.03.003

Fuadah, I. (2013). Gambaran asertivitas orang sunda sebagai perokok pasif (Skripsi tidak diterbitkan). Universitas Islam Negeri Sunan Gunung Djati Bandung, Fakultas Psikologi.

Friedberg, A. L. (2014). The sources of chinese conduct: Explaining Beijing's assertiveness. The Washington Quarterly, $37(4)$,

133-150. doi.org/10.1080/0163660X.2014.1002160

Fuspita, H., Susanti, H., \& Dewi, E. P. (2018). The influence of assertiveness training on depression level of high school students in Bengkulu, Indonesia. Enfermeria Clinica, 28 , 300-303. doi.org/10.1016/S11308621(18)30174-8

Iwamoto, K., \& Liu, M. (2010). The impact of racial identity, ethnic identity asian values, and race related on asian americans and asian international college student psychological well being. Journal of Counseling Psychology, 57(1), 79-91.

Jaenudin, U., \& Tahrir. (2019). Studi religiusitas, budaya Sunda, dan perilaku moral pada masyarakat kabupaten Bandung. Jurnal Psikologi Islam dan Budaya, 2(1), 1-8.

Kawamoto, T. (2020). The moderating role of attachment style on the relationship between self-concept clarity and selfesteem. Personality and Individual Differences, 152(September 2019), 109604. doi.org/10.1016/j.paid.2019.109604

Novianti, M. C., \& Tjalla, A. (2008). Assertive behavior on early teen. Gunadarma University.

Parham, J. B., Lewis, C. C., Fretwell, C. E., Irwin, J. G., \& Schrimsher, M. R. (2015). Influences on assertiveness: Gender, national culture, and ethnicity. Journal of Management Development, 34(4), 421439.

Phinney, J. S. (1992). The multigroup ethnic identity meassure: A new scale for use with diverse groups. Journal of Adolescent Research (7), 156-176.

Phinney, J. S., \& Ong, A. D. (2007). Concetualization and measurement of ethnic identity: current status and future directions. Journal of Counseling Psychology, 54 (3), 271-281.

Rahman, A. A., Sarbini, S., Tarsono, T., Fitriah, E. A., \& Mulyana, A. (2018). Studi eksploratif mengenai karakteristik dan faktor pembentuk identitas etnik Sunda. Jurnal Psikologi Islam dan Budaya, 1(1), 1-8. doi.org/10.15575/jpib.v1i1.2072

Ramdani, Z. (2018). Construction of academic integrity scale. International Journal of Research Studies in Psychology, 7(1), 8797. doi.org/10.5861/ijrsp.2018.3003

Rosidi, A. (2010). Mencari sosok manusia sunda. Jakarta: Pustaka Jaya.

Scott, S. (2006). The medicalisation of shyness: From social misfits to social fitness. Sociology of Health and Illness, 28(2), 133-153. doi.org/10.1111/j.14679566.2006.00485.x

Setiawan, H. (2017). Tanah dan air sunda. Depok: Api Kecil. 
Stets, J. E., \& Fares, P. (2019). The effects of race/ ethnicity and racial/ ethnic identification on general trust. Social Science Research, 80, 1-14. doi.org/10.1016/j.ssresearch.2019.02.001

Tang, L., Ma, X., Zhou, Y., Shi, X., \& Ma, J. (2019). Social relations, public interventions and land rent deviation: Evidence from Jiangsu Province in China. Land Use Policy, 86(September 2018), 406-420. doi.org/10.1016/j.landusepol.2019.05.02

Uyun, Q., \& Hadi, S. (2005). Pelatihan asertivitas untuk meningkatkan ketahanan istri terhadap tindak kekerasan suami. Sosiosains, 18(1), 1-17.
Van Heel, M., Bijttebier, P., Colpin, H., Goossens, L., Van Den Noortgate, W., Verschueren, K., \& Van Leeuwen, K. (2019). Investigating the interplay between adolescent personality, parental control, and externalizing problem behavior across adolescence. Journal of Research in Personality, $81, \quad$ 176-186. doi.org/10.1016/j.jrp.2019.06.005 
IDENTITAS ETNIK DAN ASERTIVITAS MAHASISWA SUKU SUNDA 